Research, part of a Special Feature on Scale and Governance

\title{
Effect of Policy Interventions on Food Security in Tigray, Northern Ethiopia
}

\author{
$\underline{\text { Anne van der Veen }}^{1}$ and Tagel Gebrehiwot ${ }^{2}$
}

\begin{abstract}
Following the design of a conservation-based agricultural development strategy and food security strategy, the Tigray government has implemented different pro-poor development programs over the past years to address the problems of food security. This study attempts to investigate the effectiveness of government policy interventions at different scales addressed to improve food security. Food security both at the regional and district level was investigated by deriving food balance sheets for the period 2000-2008. An empirical analysis based on a logit model was also employed to analyze household level food security status. The results of the logit model reveal that government policy interventions such as water harvesting schemes, employment generation schemes, and promotion of technology adoption significantly contribute to a higher likelihood of household food security status. The findings of the food balance sheet also indicate that the region has made some impressive development gains in improving regional food self-sufficiency, indicating the importance of government interventions in improving food security both at the household and regional level.
\end{abstract}

Key Words: effectiveness; food security; logit; policy

\section{INTRODUCTION}

Ethiopia is one of the most famine-prone countries with a long history of famines and food shortages. In Ethiopia, food insecurity among the population is widespread, and most devastatingly, there have been famines that have cost the lives of about a million people. Ethiopia is one of the world's poorest countries with indicators suggesting low levels of development. Many Ethiopians live in conditions of chronic hunger with both a low average daily energy supply ( $\mathrm{kcal} / \mathrm{capita} /$ day) of 1880 and a very high (44\%) prevalence of undernourishment (Adnew 2004).

The dimensions, causes, and consequences of food insecurity differ widely within the country. Tigray, our study region, is one of the regions most affected by recurrent drought and food security problems. Many people live in conditions of chronic hunger with a low average energy supply (Devereux $2000 a$ ). A combination of factors has resulted in a serious problem of food insecurity. The combined problems of environmental degradation, irregular rainfall, high population pressure, recurrent cycle of drought, lack of diversification in economic activities, and institutional factors threaten food security in the region.

In recognition of these problems, the Ethiopian government formulated a long-term strategy, Agriculture Development Led Industrialization (ADLI), to reverse the dire situation of small farmers and eventually alleviate its food deficiency. Cognizant of the particular problems in Tigray, the government of Tigray designed an agriculture development strategy for the region to be based on the rehabilitation, conservation, and development of natural resources, and is known as conservationbased agricultural development policy, which forms food security strategy as its major component.

Following the conservation-based agricultural development strategy and food security strategy, the regional government has launched a series of development and poverty reduction programs. Consequently, different pro-poor development programs have been implemented over the past 
years to improve food security both at the household and regional level. However, program implementation by itself is not the final step. The question of how these policies affect those groups that are vulnerable to food insecurity, and thus its policy effectiveness, needs to be evaluated after a certain period of time to assess what changes can be attributed to the introduction of a particular intervention program or policy (Dunn 2004, Kumar 2005). Policy or program evaluations are also required to inform policymakers and the public on which public actions have been effective and which ones have not worked well in solving social problems (Babbie 2003, Wond and Macaulay 2010).

In the literature, attention has been paid to analyzing the causes of food insecurity and dynamics of poverty, but studies on the impact of the government interventions on food security are limited. There is a small body of research that assesses the impact of food aid programs on household food security and welfare and to a more limited extent, nutrition (Barrett 2002). Important exceptions include Quisumbing (2003), Yamano et al. (2005), and Holden et al. (2006). In a recent paper, Gilligan and Hoddinott (2007) examined the importance of foodfor-work (FFW) programs on consumption, food security, and assets in rural Ethiopia. Given the objectives of the government policy, i.e., ensuring food security and concomitantly addressing its causes in the long run, the evaluation of the effects of these integrated interventions upon food security is pertinent. In this study, we attempt to evaluate the effect of government policy interventions aimed at addressing the principal issues of food insecurity both at the regional and household level. The specific objectives of this paper are to analyze and evaluate regional food self-sufficiency at different governance scales and to determine the influence of government interventions on household food security based on indicators related to policy instruments. We used three scale levels of analysis to demonstrate our study.

\section{Defining food security}

Food security is a concept that has evolved over time. According to Hoddinott (1999), there are approximately 200 definitions and 450 indicators of food security. In the mid-1970s, definitions of food security focused on aggregate food supplies at national and global levels, and analysts advocated production self-sufficiency as a strategy for nations to achieve food security, e.g., in the Food Availability Decline theory (Sen 1981, Devereux 1993). This view focused merely on food production variables, i.e., supply side, and overlooked the multiple forces that in many ways affect food access, i.e., demand side variables. It said nothing about people's income and purchasing power.

In the 1980s, the focus of food security shifted from global and national levels to household and individual levels. Definitions further underwent another round of evolution after the 1996 World Food Summit. According to the refined definition, food security is seen as a situation that exists when all people, at all times, have physical, social, and economic access to sufficient, safe, and nutritious food that meets dietary needs and food preferences for an active and healthy life (FAO 2002). This definition is broader than the previous definitions, for example, that of the World Bank (1986), which was summed up by Maxwell and Frankenberg as "secure access at all times to sufficient food for a healthy life" (Maxwell and Frankenberger 1992:8). As a result, a synthesis of these definitions, with the main emphasis on availability, access, and utilization, serves as a working definition in projects of international organizations.

Apart from differentiating between spatial dimensions, the understanding of food security also includes a time dimension, describing the intensity and characteristics of a household's food insecurity. Consequently, food insecurity can be "chronic" or "transitory." A constant failure to access food is distinguished as chronic, whereas a temporary decline is considered as transitory food insecurity (Maxwell and Smith 1992). Consistent handling of food security thus requires integrating time and spatial dimensions.

\section{Food insecurity and its underlying causes}

As in other sub-Sahara African countries, Ethiopia is one of the most famine-prone countries with a long history of famines and food shortages that can be traced back to $250 \mathrm{BC}$ (Webb and von Braun 1994). In Ethiopia, food insecurity among the population is widespread. Serious food shortages and high levels of malnutrition continue to affect a large number of people in several parts of Ethiopia.

The debate in Ethiopia on the causes of inconsistent food security between regions and communities has 
fuelled highly contested viewpoints between the academic disciplines and in development thinking over the past few decades, giving rise to a proliferation of demographic, economic, and political emphases across the food security literature (Devereux 2000b, Maxwell 2001). The recent 2002-2003 food crisis has been evaluated to be the result of a suite of political, social, and economic factors rather than only the result of environmental stressors leading to production shortfalls. The causes were complex: the country is prone to drought. Drought and environmental degradation are important natural factors that make households vulnerable to food shortage. The agricultural sector is nearly totally dependent on rainfall and any weather fluctuation or rainfall failure means loss of a major livelihood source that always accentuates food deficit. Von Braun (1991), for example, reported that a $10 \%$ decline in rainfall below its long average results in a $4.4 \%$ reduction in national food production.

Frequent droughts are not the only factors contributing to Ethiopia's food security problems. Like many African countries, Ethiopia confronts several environmental issues that are particularly problematic for the agricultural sector. Poverty and food insecurity in the drylands of Ethiopia are caused by land degradation that amplifies the negative impacts of droughts (Aune et al. 2001, Tewolde Berhan 2006). Low agricultural productivity, poverty, food insecurity, and land degradation are pervasive and interconnected problems in the Ethiopian highlands (Holden and Shiferaw 2004, Pender and Gebremedhin 2008). These factors often interact with one another resulting in a reinforcing cycle of the poverty, food insecurity and natural resources degradation trap. This problem manifests itself in recurrent drought affecting millions of people.

Social factors such as population pressure, traditional farming systems and practices, and economic limitations like poor infrastructural services, shortage of farm land and other productive assets, are also factors responsible for households' food insecurity. Tigray's population growth remains very high with an annual rate of approximately $2.5 \%$, putting pressure on existing amenities. In addition to natural and socioeconomic factors, government policy failures or inappropriate development strategies and governance are claimed to be one of the main factors for the recurrence of food shortage, poverty, and underdevelopment in many African countries (Paarlberg 2002, Bird et al. 2003). Ethiopia suffered from misguided economic policies under the socialist Dergue regime, which ruled from 1974 until 1991. The policy framework of the past governments and decades long civil war in the region have played a role in exacerbating food insecurity. With respect to the cause of the 1977-1988 Ethiopian famine, Downing (1995) notes the correlation between famine areas and specific government policies. To summarize, food security is a deep rooted problem in Ethiopia in general and in Tigray in particular. It is a multifaceted issue and its attainment demands integrated policies and technologies that can contribute to increased production and improved food security.

\section{Government policy instruments for food security}

The Ethiopian government formulated a long-term strategy to reverse the dire situation of small farmers and eventually alleviate its food deficiency, and concomitantly, promote the manufacturing sector to provide essential consumer goods. The adopted strategy is the agricultural development-led industrialization strategy (ADLI), which takes agriculture as its point of departure and growth engine (FDRE 1994). Cognizant of the particular problems in Tigray, the government designed the agriculture development strategy for the region to be based on the rehabilitation, conservation, and development of natural resources, and is known as the conservation-based agricultural development policy.

The long-term development strategy of the government aims at promoting sustainable management of natural resources and increasing agricultural production, and ensuring food security and nutrition of the population. The strategy focuses on improving the production and productivity of smallholder agriculture through generation, adoption, and diffusion of suitable farm technologies in the form of improved inputs and farming methods, provision of credit, and rural asset building. To mobilize small farmers and the dissemination of better farming practices, the development strategy has been operationalized via the Participatory Demonstration and Extension Training System (PADETS). 
Food security strategy is the major component of the ADLI policy. The first version of the food security strategy was issued in 1996 and revised in 2002 highlighting the government's plan to address causality and effects of food insecurity in the country. The strategy envisages developing an agriculture-based economy by raising farm productivity and income. Furthermore, the food security measures aim to promote and strengthen micro- and small-scale enterprise development, improving the food marketing system, promoting and strengthening supplementary employment, income generating schemes, and credit services to address the demand side problems. As an example, in our study the government interventions carried out to tackle the problems of food security are discussed in the following section.

\section{Intervention to enhance food availability}

Food availability is one of the three conditions of food security as defined by the World Food Summit. Increasing the production and productivity of agriculture in a sustainable manner could address the problem of food shortage by making more food available and by generating employment and income. With this in mind, the regional government in Tigray has put emphasis on creating substantial growth and expansion in the agricultural sector that would considerably reduce the spread of poverty and food insecurity in the region.

Accordingly, different interventions were carried out to raise agricultural production by giving utmost attention to agricultural extension services. One of the major components of the extension package is the use of fertilizers and improved seeds. As indicated, the most plausible way to eradicate poverty is to increase food supply in the region and create the opportunity for people to attain food security. One of the means that has been followed to expedite the availability of enough food, which has been the obsession of the regional government, has been the increased use of fertilizers by smallholding farmers. Furthermore, several arrangements have also been developed to facilitate farmers' access to rural credit to enable them to purchase fertilizer and other agricultural inputs. The regional government, Dedebit Credit and Saving Institution (DECSI), and regional cooperative associations have made efforts to provide credit for such purposes.
The extension services also focused on introducing better and improved agricultural practices. These practices were accompanied by the development of infrastructures that enable farmers to sell their products and buy farm inputs more easily. Development agents were assigned in each tabia (lowest administrative level) to train farmers by demonstrating the benefits of the program.

Furthermore, the government has introduced a variety of water harvesting schemes, which is considered as the single most important means to increase agricultural productivity and address the problems of water shortage. Accordingly, extensive pond construction and digging of water wells, traditional river diversion schemes, and construction of small-scale irrigation schemes have been undertaken in different parts of the region since 2002. A total of 101,537 pond schemes were constructed during the period 2002-2005, of which $75.74 \%$ are functional. Traditional river diversion schemes and small-scale irrigation schemes were constructed in different parts of the region. Consequently, the amount of land under irrigation has increased from 4773 hectares in 2000 to $29,734.6$ hectares in 2008.

\section{Interventions at household level}

In addition to programs oriented to agricultural production, two intervention programs, i.e., the integrated household level extension program known as the food security package (FSP) program and the food-for-work (FFW) program, were implemented to fight food insecurity at the household level. The FSP was launched in 2002 with the overall aim of generating and diversifying rural employment and income that can reduce risks for food insecure households. At the household level, the FSP program intended to secure food by diversifying the income base of the poor through provision of credit for a range of activities in a package. A household can be financed for a range of activities (package) and loans are disbursed on an individual basis. Although the components of the package for which loans are granted differ from area to area to suit agroecological and other needs, the basic components include livestock, i.e., oxen and cows, small animals, i.e., sheep and goats, poultry, beehives, seed, and fertilizer. In 2003, the number of households chronically affected by food insecurity and covered by the food security package program was 49,427 rural households (6.7\%), and 
the number of beneficiaries increased to 629,328 rural households $(86 \%)$ in 2008.

The FFW program on the other hand, served as a safety net for poor communities in food insecure areas. The FFW programs are mainly meant to provide employment and generate public goods such as physical and social infrastructures. It is a way of utilizing the food aid to development ends, while at the same time transferring food to the poor, i.e., a transition between emergency relief and the achievement of long-term development objectives. Ehui and Pender (2005) found that food-for-work and cash-for-work projects are main sources of nonfarm income in Tigray.

\section{DATA AND METHODS}

\section{The study area}

The study area, Tigray, is in northern Ethiopia and has a rugged terrain, ranging between 400 to almost $4000 \mathrm{~m}$ above sea level, covering a total area of $53,000 \mathrm{~km}^{2}$. It lies between latitudes $12^{\circ} 15^{\prime} \mathrm{N}$ and $14^{\circ} 57^{\prime} \mathrm{N}$ and longitudes $36^{\circ} 27^{\prime} \mathrm{E}$ and $39^{\circ} 59^{\prime} \mathrm{E}$. The region is structured into six administrative zones and 34 districts (Fig. 1), and its population is estimated to be about 4.5 million of which $80 \%$ live in rural areas. The climate is predominantly semiarid with irregular rainfall and frequent drought periods. Average annual rainfall ranges between 500 and $900 \mathrm{~mm} \mathrm{yr}^{-1}$, with a unimodal pattern, except in the southern part of the study area where a second, smaller rainy season allows local growing of two successive crops within one year (Nyssen et al. 2005). Tigray is one of the regions most affected by food security problems. Despite efforts being made and some signs of change, poverty and food insecurity in Tigray is staggeringly high.

\section{Methods}

\section{Determining Food Balance Sheet}

The concept of food security can be analyzed for units at different conceptual levels and the exact dimensions that need to be measured should vary depending on the level of analysis chosen. At a national or regional level, the status of food security can be analyzed in terms of supply indicators by looking at the ability of the country or region to obtain sufficient food to meet the needs of all citizens. The most widely used indicator is the quantity of food available as compared with needs. Availability is a function of domestic production, imports, food aids, and security stock. Of these, domestic production is critical in ensuring food availability at both regional and household levels.

The change in the regional level of food availability was analyzed first by computing a so-called Food Balance Sheet (FBS) for the period 2000-2008. FBS is the principal tool used for calculating national food security, which is used to determine the expected food deficit or surplus, the necessary food import, and/or food aid requirements (Frankenberger 1992). The Ethiopian government has designated $2100 \mathrm{Kcal}$ (or $225 \mathrm{~kg}$ of cereals per person per annum) as a minimum acceptable weighted average nutritional requirement (FDRE 2001, MoFED 2002), and we used this threshold level to determine the annual regional food requirements for the period. Based on the annual net cereal production, we determined a self-sufficiency ratio (SSR), which is measured as the ratio of the sum of net production of cereals to the requirement of food. Moreover, we derived a regional food availability ratio (FAR), which is the ratio of the total food supply to the food requirement. Tigray is categorized as a low income food deficient region dependent on food aid. There are no regional food imports, though there are at the national level. Total food supply is therefore determined as the sum of net domestic produce and total food aid.

For deriving the FBS both at regional and district levels, data on annual agricultural production and population were collected from Tigray Bureau of Finance and Economic Development (BoFED). Data on fertilizer, improved seed supply, and irrigation coverage were also acquired from BoFED. Also, data on food aid was acquired from the Disaster Prevention and Preparedness Commission. Historical records of monthly precipitation data for the period 1954-2008 were acquired from the Ethiopian National Meteorological Services Agency.

\section{Household survey}

Furthermore, we used data from a household survey conducted in the districts of Kilte Awelaelo and Enderta. A two-stage random sampling procedure was used to select rural households. At the first stage, six villages (locally called tabia) were selected randomly. In the second stage, random 
Fig. 1. Administrative map of Tigray region, Ethiopia

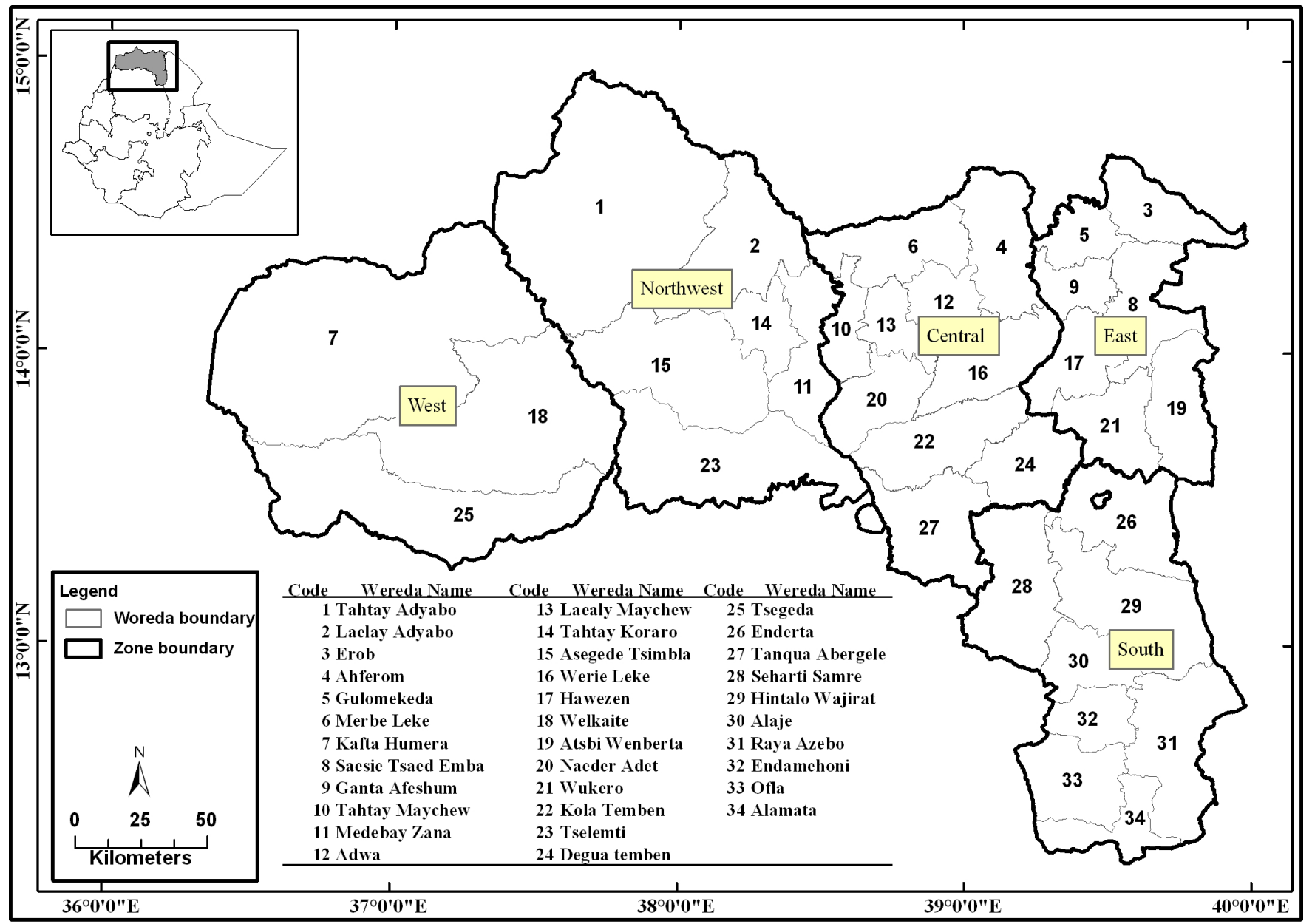

Fie 1 Groom thic location of Toras region Ethiopia

sampling techniques were employed to draw 90 sample households from the villages of Abrha Atsibha, Kihen, Tsegreda, Lemlem, Felege Selam, and A'rato. Data on the basic characteristics of households in terms of demography, resource endowment, economic activities, income, crop production, farm input use, as well as household coping strategies were collected. To generate the required data, different methodological approaches such as in-depth interviews, focus group discussions, and field observations were employed. Data on income from food-for-work was computed from the number of labor-days supplied for the food- for-work program reported by all participating households.

To measure household food security, first a minimum level of subsistence necessary to maintain healthy living for the population under study was defined, below which households are classified as food-insecure. We used the $2100 \mathrm{kcal}$ as a cut-off value between food-secure and food-insecure households. Then, the daily per capita calorie consumption was determined by dividing the estimated food supply to the household. Thus, those households who have energy per adult equivalent 
below the minimum subsistence requirement are deemed to be food insecure, and those who managed to attain the cut-off value are considered to be food secure households.

Once we categorized the sample households as food-secure and food-insecure, we selected a model to elicit the factors influencing the food security status of households at the study area. A variety of statistical models can be used to establish the relationship between household characteristics and food insecurity. The use of the logit or probit model is recommended when the dependent variable is dichotomous as a panacea of the drawback of the linear regression model (Gujarati 2003). Many researchers tend to choose the logit model because of its comparative mathematical and interpretational simplicity (Hosmer and Lemeshew 1989). Therefore, we employed the logit model for this study. Thus, the model uses food security status of households as the dichotomous dependent variable, which took a value of 1 if a household was found to be food secure, 0 otherwise. The logistic regression model employed to determine food security status is:

$$
\pi_{i}=E\left(Y=1 \mid X_{i}\right)=\frac{1}{1+e^{-\left(\beta_{0}+\sum_{k} \beta_{k} \chi_{i k}\right)}}
$$

Where $\pi_{\mathrm{i}}$ is the conditional probability that household $\mathrm{i}$ is food secure, $\beta_{0}=$ constant term, $\beta_{\mathrm{k}}=$ coefficient for $k^{i t h}$ independent variable $\mathrm{x}$, with $\mathrm{i}=$ $1, \ldots, n$, for $n=90$.

Reviews of literature were used to identify the potential determinants of household food security with basic emphasis on factors linked to government policy instruments introduced to address the problem of food security in the study area. Therefore, food-for-work income, technology adoption, farmland size, access to irrigation, type of household head, age of household head, education level of household head, oxen ownership, and offfarm activity were selected to analyze whether they explain a household's food security or not. All the factors were a priori expected to have a positive impact on the food security status of households.

According to the literature, subsistence farming, by its nature, is production for direct consumption. Any farm input that augments agricultural productivity is expected to boost the overall production. This contributes toward attaining household food security (Brown 2004). Thus, fertilizer and improved seed are expected to have positive effects. Fertilizer use was measured on the basis of amount of fertilizer used by a household. Improved seed was measured on the basis of whether or not a household applies improved seed (dummy variable).

Income determines the household's ability to secure food and it remains to be an important variable that explains the characteristics of food secure and food insecure households. Income earned in the form of one's own production or income earned from other activities that might be related to employment as daily wage laborers could enhance the capacity of the household's access to food. Therefore, a positive relationship is expected between a household's participation in food-for-work and food security status in this study. Since food-for-work income is linearly proportional to the number of working days, it can serve as a proxy for FFW income. Similarly, nonfarm activity has been found to be positively correlated with income and wealth, and may offer a pathway out of poverty. Improved access to nonfarm sources of income is likely to be good for household welfare, including food security (Holden et al. 2004). Employment in off-farm and nonfarm activities enables farmers to modernize their production by giving them opportunity to reduce the risks of food shortage during periods of unexpected crop failures. From this perspective, it was expected that a household's participation in off-farm activity positively influences the household's food security. In this study, participation in off-farm and nonfarm activities was measured by whether or not a household was engaged in those activities, i.e., a dummy variable was used. We considered the offfarm job created through government's employment generation scheme.

Education is an additional factor that is also thought to influence the food security status of households. Education equips individuals with the necessary knowledge of how to make a living. Literate individuals are keen to get information and use it. Hence, it is supposed that educational attainment by the household head could lead to awareness and benefit from the possible advantages of modernizing agriculture by means of technological inputs, which in turn would enhance households' food security. Educational status further reflects the household's human capital and it was thus assumed 
to play a role in determining a households' food security. Households led by educated heads take a value of 1 whereas those led by uneducated heads take a value of 0 .

Farmland size is a continuous variable. We expected farmland size to affect the food security status of households positively. According to Najafi (2003), food production can be increased extensively through expansion of areas under cultivation. Therefore, under subsistence agriculture, holding size is expected to play a significant role in influencing farm households' food security. The size of farmland owned by a household was determined by summing the fragmented plots and converting into hectares.

For age, the assumption was that the higher the age of the household head, the better the food security situation because there are more options of making food available from both agricultural and nonfarm opportunities. Older persons are more risk aversive, and tend mostly to diversify their production activities. As a result, the chances of such a household to be food secure is higher. Hofferth (2004), in his study, further argued that the higher the age of the household head, the more stable the economy of the farm household because older people also have a relatively richer experience with their social and physical environments as well as greater experience in farming activities. However, it could also be negatively correlated with food security indicating that as the head ages, he/she might be less efficient in carrying out demanding farm operations resulting in low farm production and productivity. Male-headed households were expected to have higher food security status than their female-headed counterparts because it is assumed that male-headed households are in a better position to supply more labor to do the farm work.

Use of irrigation is a good strategy for promoting crop production in the region. Thus, it is hypothesized that a household's access to irrigation positively influences their food security status. A household that has access to irrigation activities took a value of 1 and households who did not engage in irrigation scheme took a value of 0 .

Ox ownership is another determinant of food security status of households. Oxen serve as a source of traction in many developing countries, thereby significantly affecting a household's crop production. Animal traction power enables households to cultivate greater areas of land and to execute agricultural operations in a timely fashion (Govereh and Jayne 1999). Therefore, a positive relationship between ox ownership and food security was expected in this study. The data on ox ownership was used by converting it into tropical livestock unit (TLU) which results as: $1 \mathrm{Ox}=1.1$ TLU

\section{RESULTS AND DISCUSSIONS}

\section{Enhancing food availability at the regional level}

Domestic production of food grains or food availability was considered to evaluate government efforts to boost production and ensure food security. Results of our FBS reveal that food requirement in the study region increased by $2.4 \%$ while the food availability improved by $7.7 \%$ (Table 1 ). As a result, the food deficit declined by $32 \%$ over the period 2000-2008. The self- sufficiency ratio (SSR) increased by $8.6 \%$. The self-sufficiency ratio expresses the magnitude of production in relation to domestic utilization. Based on the official food grain production figures, the food grain SSR for Tigray region is gradually increasing. The lowest self-sufficiency rate was found in 2002 and was attributed to crop failure caused by the severe drought that occurred all over the country, indicating the vulnerability of the agricultural sector to the natural vagaries. Moreover, the food availability ratio has also increased by $7.7 \%$. Crop production has increased dramatically over the period of 2003-2008 (Table 1). The increase is mainly due to the expansion of cultivated land, increased and better use of improved technologies, including water conservation, fertilizer application, improved seeds, pest control, and the expansion of irrigation schemes.

The area under food grain cultivation increased dramatically since 2005 , showing a $95.7 \%$ increase compared with the year 2000 (Table 2). Furthermore, fertilizer use experienced a steady rise from about 58.6 tons in 2000 to about 166.2 tons in 2008. The amount of improved seed supply also increased since 2005. A decline in fertilizer and improved seed use was observed in the period 2002-2004. This reduction is attributed to an increase in input prices because more expensive transportation costs kept prices higher and was compounded by lack of a competitive improved 
Table 1. Food Balance Sheet for Tigray Region, 2000 - 2008

\begin{tabular}{|c|c|c|c|c|c|c|c|c|c|c|c|}
\hline No. & Variable & 2000 & 2001 & 2002 & 2003 & 2004 & 2005 & 2006 & 2007 & 2008 & $\begin{array}{l}\text { Growth rate } \\
\qquad \%)\end{array}$ \\
\hline 1 & $\begin{array}{l}\text { Production } \\
\text { of cereals in } \\
(" 000 “ \mathrm{MT})\end{array}$ & 748.4 & 843.3 & 414.0 & 608.1 & 657.9 & 715.0 & $1,115.9$ & $1,275.9$ & $1,335.2$ & 11.2 \\
\hline 2 & $\begin{array}{c}\text { Less } 15 \% \\
\text { Post harvest } \\
\text { loss }\end{array}$ & 112.2 & 126.5 & 62.1 & 91.2 & 98.7 & 107.2 & 167.4 & 191.4 & 200.3 & \\
\hline 3 & Less $6 \%$ seed & 44.9 & 50.6 & 24.8 & 36.5 & 39.5 & 42.9 & 66.9 & 76.5 & 80.1 & \\
\hline 4 & $\begin{array}{l}\text { Net production } \\
(1-2-3)\end{array}$ & 591.2 & 666.2 & 327.1 & 480.4 & 519.7 & 564.9 & 881.6 & $1,007.9$ & 1054.8 & 11.2 \\
\hline 5 & Food Aid & 9.8 & 1.3 & 26.5 & 18.1 & 6.6 & - & - & - & - & \\
\hline 6 & $\begin{array}{c}\text { Total grain } \\
\text { available }(=\text { total } \\
\text { supply) } \\
(4+5)\end{array}$ & 601.0 & 667.6 & 353.6 & 498.6 & 526.4 & 564.9 & 881.6 & $1,007.9$ & $1,054.8$ & $10 . .33$ \\
\hline 7 & $\begin{array}{l}\text { Total population } \\
\text { ("000") }\end{array}$ & 3,695 & 3,797 & 3,901 & 4,006 & 4,113 & 4,223 & 4,335 & 4,454 & 4,576 & \\
\hline 8 & $\begin{array}{c}\text { Food } \\
\text { requirement at } \\
2.25 \mathrm{Qt} \text { per } \\
\text { person ("000" } \\
\text { MT) }\end{array}$ & 831.3 & 854.3 & 877.7 & 901.3 & 925.4 & 950.2 & $975 . .4$ & $1,002.1$ & $1,029.6$ & 2.41 \\
\hline 9 & $\begin{array}{c}\text { Food Balance } \\
\qquad(6-8)\end{array}$ & -230.3 & -186.7 & -524.1 & -402.8 & -399.0 & -385.3 & -93.8 & 5.8 & 25.2 & 31.94 \\
\hline 10 & $\begin{array}{c}\text { Self-Sufficiency } \\
\text { Ratio } \\
(4 / 8)\end{array}$ & 0.7112 & 0.7798 & 0.3726 & 0.5330 & 0.5616 & 0.5945 & 0.9038 & 1.01 & 1.024 & 8.55 \\
\hline 11 & $\begin{array}{c}\text { Food } \\
\text { Availability } \\
\text { Ratio } \\
(6 / 8)\end{array}$ & 0.7230 & 0.7814 & 0.4028 & 0.5531 & 0.5688 & 0.5945 & 0.9038 & 1.01 & 1.024 & 7.72 \\
\hline & $\begin{array}{l}\text { Average annual } \\
\text { precipitation } \\
(\mathrm{mm})\end{array}$ & 422 & 643 & 461 & 480 & 576 & 617 & 677 & 543 & 561 & 0.05 \\
\hline
\end{tabular}

Source: Computed by the authors, using data from Regional Bureau of Finance and Economic Development, and the Regional Disaster Prevention and Preparedness Commission, Tigray 
seed market sector. Also, a substantial number of farmers were not able to recoup their investment because of the drought in 2002 and this situation generated a loss of confidence for some years in buying into credit schemes. However, the arrangements worked out to facilitate farmers' access to rural credit to enable them to purchase fertilizer and other agricultural inputs contributed to the increase in fertilizer consumption over the period.

The extension program was expanded substantially and is producing tangible results in terms of increasing productivity. The massive extension programs on soil and water conservation had significant impacts on changing the environment. In a related study, Pender and Gebremedhin (2008) found that land investments and land management practices introduced in the region had a significant impact on the value of crop production and predictive crop productivity. The role of development agents was also pivotal in implementing the extension programs. The number of development agents assigned to every village center has increased from one in 2000 to three in 2006 with specialization in crop cultivation, natural resource protection and conservation, and animal husbandry. This new system of organization has helped in narrowing the gap in the extension workers to farmers ratio, and by clearly demonstrating, these agents trained as many farmers as possible in the benefits of food security packages.

Furthermore, because of the variety of water harvesting schemes introduced since 2002, the amount of land under irrigation has increased from 4773 ha in 2000 to $29,734.6$ ha in 2008. Thus, improvements in water use efficiency helped the region to increase production over the period and these interventions also gave farmers an opportunity to access water resources and increased the likelihood of using improved inputs because of the reduced risk of crop failure. However, the implementation of the water harvesting scheme program was not without problems. There were signs of attempts to implement these programs through the use of coercive persuasion while households were voicing problems with the technology in some areas of the region.

Finally, the new coalition for food security established in 2003 between the national government and development partners to search for a long lasting solution to the issue of food security has created an opportunity to obtain substantial amounts of financing for implementing the food security program. Given the commitments of the regional government, we believe that this has played a fundamental role in the financing and smooth implementation of the program over the period 2004-2008.

In general, the results of the analysis on the Food Balance Sheet reveal that food availability and regional food self-sufficiency increased over the period 2000-2008, with dramatic increases during 2005-2008. The analysis reveals that increases in productivity were consistent and that the regional crop production in 2007 and 2008 met the food requirement levels necessary for a per capita dietary energy supply of 2100 calories. On the other hand, the temporal average annual precipitation exhibited high variability over the period with a coefficient of variation of $16 \%$, which is high compared to the national figure of $8 \%$, while the production of cereals showed a consistent increase since 2003. This indicates that the policy instruments put in place improved food self-sufficiency at a regional level. Government official data also revealed that the region has made some impressive development gains in the past few years. This data suggest that GDP growth averaged $12.1 \%$ while agriculture grew on average by $18.7 \%$ between 2000 and 2008 . This economic growth has raised the living standard of many poor households from a very low base. Similar development gains have been observed in the country over the same period (Loening and Imru 2009).

However, food supply indicators at the regional level can provide some useful information regarding trends in food availability but they are often too aggregated to detect pockets of food deficit in a given district. Similarly, a Food Balance Sheet is not usually drawn upon at a disaggregated basis to detect differences across regions or districts (Davies et al. 1991, as cited in Frankenberger 1992). Thus, looking at the spatial effect of government interventions across districts is vital to draw a concluding remark. Consequently, the findings of the FBS computed at a district level (see Appendix) reveal that improvements in the food selfsufficiency ratio are observed in all districts except for Naeder Adet district, where the food self- 
Table 2. Distribution of agricultural inputs and area cultivated, 2000-2008

\begin{tabular}{cccc}
\hline \hline Year & $\begin{array}{c}\text { Fertilizer consumption } \\
\text { (Ton) }\end{array}$ & $\begin{array}{c}\text { Improved seed consumption } \\
\text { (Ton) }\end{array}$ & Area cultivated (Hectare) \\
\hline 2000 & 58.6 & 9.7 & 560,510 \\
2001 & 135.7 & 7.3 & 635,100 \\
2002 & 132.9 & 6.5 & 566,237 \\
2003 & 117.0 & 0.34 & 446,372 \\
2004 & 117.0 & 0.34 & 727,944 \\
2005 & 141.8 & 10.9 & 701,905 \\
2006 & 134.2 & 17.9 & $1,036,518$ \\
2007 & 147.8 & 27.7 & $1,064,595$ \\
2008 & 166.3 & 34.7 & $1,097,034$ \\
\hline
\end{tabular}

Source: Bureau of Finance and Economic Development, Tigray.

sufficiency ratio is decreased by $6.1 \%$. In general, the region had an impressive performance on improving its food self-sufficiency on a sustained basis since about 2004.

\section{Empirical results of the household survey}

In Table 3, we present our results on the household survey. The logit model was first checked by using the likelihood ratio chi-square statistic, which is usually used to test the relation of the dependent variable with the selected variables in the model. The model chi-square statistic, which is obtained by the difference of the value of the unrestricted log likelihood function (with all the parameters) and the restricted log likelihood function (with only one parameter, $\beta_{0}$ ) was found to be 37.509 , with $\mathrm{p}<$ 0.001 , indicating that at least one of the parameters in the equation is nonzero or significant. This represents the fit of the model when the most basic model is fitted to the data, moreover it shows that the log odds of household food security is related to the independent variables.

With regard to the predictive efficacy of the model, the results shows that of the 90 households included in the sample, $90 \%$ are correctly predicted. Of the 90 observed households in the sample, 51 are food secure $(56.7 \%)$ of which $90.2 \%$ are correctly predicted by the model. Of the 90 observed households, 39 are food insecure $(43.3 \%)$ of which $89.7 \%$ are correctly predicted. Overall, the model classifies $90 \%$ of the households. The Hosmer and Lemeshow (1989) test statistic shows a significant association between the observed and the model's prediction of a household's food security status.

Among the 10 factors considered in the model, nine were found to have a significant impact in determining household food security. These are farm size, access to irrigation, improved seed use, fertilizer use, food-for-work income, off-farm activity, ox ownership, type of household, and education, significant at $5 \%$.

The regression results show a positive relationship between fertilizer use and the probabilities of household food security, implying that the likelihood of food security increases with the farmers' use of fertilizer. Similarly, an increase in improved seed application has a positive effect on household food security. This implies that households could improve their food security 
Table 3. Logit estimation on the likelihood of household food security

\begin{tabular}{lccc}
\hline \hline Variable & B & Sig. & Exp(B) \\
\hline Constant & -9.515 & 0.004 & 0.000 \\
Farm Size & 2.889 & 0.041 & 17.982 \\
Access to Irrigation & 0.803 & 0.016 & 2.232 \\
Improved Seed Use & 0.372 & 0.036 & 1.450 \\
Fertilizer Use & 0.187 & 0.019 & 1.206 \\
Food-for-work income & 0.002 & 0.014 & 1.002 \\
Off-Farm & 0.200 & 0.002 & 1.222 \\
Ox Ownership & 0.628 & 0.038 & 1.874 \\
Male Headed & 0.658 & 0.027 & 1.932 \\
Education & 0.678 & 0.046 & 1.970 \\
Age Of HH Head & -0.092 & 0.115 & 0.912 \\
Percentage of correct prediction & 0.900 & & \\
Hosmer \& Lemeshow (1989) test statistic & 17.901 & & \\
Log likelihood value & 37.509 & & \\
\hline
\end{tabular}

situation by increasing use of modern technological inputs in their farm operations. Feleke et al. (2005) also found use of fertilizer positively and significantly related to food security. Thus, the regional government's obsession with increasing the use of fertilizers and improved seeds by smallholding farmers as a means to expedite the availability of enough food is positively influencing the likelihood of household food security. However, policy makers have to make efforts to curb the exorbitant fertilizer and improved seed price.

Access to irrigation is another strong factor positively associated with food security and welfare. The finding revealed that there is a positive relationship between households' food security and access to irrigation activities. The positive relationship indicates access to irrigation reduces the likelihood of food insecurity among the sample households. Furthermore, a test of association was carried out to analyze the impact of water harvesting schemes by employing a two-way counter factual test (households with access to irrigation and those with out). The chi-square test result, Spearman's rho, is found to be 0.433 (significant at $5 \%$ ) indicating that there is a significant association between a household's food security status and access to irrigation. The counter factual test further illustrates that a household with access to irrigation activity has a higher mean annual income. Thus, the introduction of water harvesting and irrigation schemes are offering farmers a possibility of mitigating water stress, reducing risks of crop failures, and thereby reducing the risk of food insecurity among the sample households.

Food security is an issue of income, either income from one's own production of food, or income earned from activities that allow access to food through the market. The regression result shows that 
there is a positive relation between food-for-work income and household food security. However, the effect of a unit increase in food-for-work income on food security is marginal. The findings further revealed that households with alternative off-farm activities are more likely to be food secure, a finding similar with Nyariki et al. (2002) who found involvement in off-farm activities positively and significantly affected food security in Kenya. Households that manage to secure supplementary income from off-farm activities have better access to the food they need than those households that do not. Thus, households with multiple income sources are also better off in terms of food security, and creating access to alternative employment opportunities is among the key measures necessary to ensure food security. This highlights the importance of food security package programs that create employment opportunities for farmers to diversify their income sources.

The results of the logit model indicated that sample households that had a larger farm size had a high probability of being food secure. This indicates that the amount of land held by a household influences food security positively. The possible justification is that farm households that had larger farms had a better chance to produce more and to diversify the crops they produce.

The results of the analysis also show that education is important in reducing food insecurity at household level. The impact of education in increasing food consumption and reducing food insecurity is significant in rural areas, i.e. households with higher levels of literacy are more likely to earn more income and enjoy increased food consumption than those households with lower levels of literacy. The $\operatorname{Exp}(\beta)$ statistic for age of the household head suggests that the odds in favor of being food secure decreased by a factor 0.912 . This means that an increase in the age of the household head decreases the likelihood for the household to become food secure. This is possibly because as the head ages, he/she might be less efficient in carrying out demanding farm operations resulting in low farm production and productivity.

The regression result also shows that ox ownership, in tropical livestock unit, of households has a significant and positive relationship with the likelihood of household food security. A unit increase in ox ownership increases the probability of household food security. This is an indication that ox ownership acts as a hedge against food insecurity in the study area. The logit analysis further reveals that government interventions on creating alternative employment opportunities, irrigation, household asset creation, and increased agricultural input supply are among the key measures necessary to increase food security at the household level. However, the effect of food-for-work programs on household food security is found to be significant but marginal in this study.

\section{CONCLUSION}

The primary objective of this study was to assess the effectiveness of policy interventions at different scales addressed to tackle the problem of food security. To this end, effects of intervention on improving regional food availability were examined, a food balance sheet was constructed, and the food security at the household level was studied using a logit model. The findings of our study reveal that food availability and food selfsufficiency at the regional and district level improved over the period 2000-2008. The food selfsufficiency ratio (SSR) in the region increased by $8.6 \%$. As a result, the food deficit declined by $32 \%$ over the time period. The findings of the household survey also confirm the importance of the government's integrated household level extension program, i.e., the food security package program and food-for-work program, in influencing the household's food security status, indicating the role of government policy instruments as important tools to ensure food security at the household level.

Effect of government interventions on food security should therefore be viewed from different scales of analysis. Only research aimed at the interplay of analysis at different scales is able to unravel the effectiveness of governance in ensuring food security for a certain region.

Responses to this article can be read online at: http://www.ecologyandsociety.org/voll6/iss1/art18/ responses/

\section{Acknowledgments:}

The study was conducted under the support of the Ensure Project. The ENSURE project is financed by

the European Commission under the 7th Framework Program for Research and Technology Development, Area "Environment", Activity 6.1 "Climate Change, Pollution and Risks". The paper 
reflects the author's views and the European Commission is not liable for any use that may be made of the information contained therein. We are grateful to the two anonymous reviewers for their comments/suggestions which have helped to improve the original version of the paper.

\section{LITERATURE CITED}

Adnew, B. 2004. Food insecurity in Ethiopia. Journal of Agricultural and Development Economics 1:138-158.

Aune, J. B., M. T. Bussa, F. G. Asfaw, and A. A. Ayele. 2001. The ox ploughing system in Ethiopia: can it be sustained? Outlook on Agriculture 30:275-280.

Babbie, E. 2003. The practice of social research. Wadsworth, Belmont, California, USA.

Barrett, C. B. 2002. Food security and food assistance programs. Pages 2103-2190 in B. Gardner and G. Rausser, editors. Handbook of agricultural economics. Elsevier, Oxford, UK.

Bird, K., D. Booth, and N. Pratt. 2003. Food security crisis in Southern Africa: the political background to policy failure. International Development Department, Birmingham University, Birmingham, UK.

Brown, L. 2004. World food security deteriorating: food crunch in 2005 now likely. Earth Policy Institute, Washington, D.C., USA.

Devereux, S. 1993. Theories of famine. Harvester Wheatsheaf, New York, New York, USA.

Devereux, S. 2000b. Famine in the 20th century. IDS Working Paper 105, Institute of Development Studies, University of Sussex, Brighton, UK.

Devereux, S. 2000a. Food insecurity in Ethiopia. A discussion paper for DFID. Institute of Development Studies, University of Sussex, Brighton, UK.

Downing, T. E. 1995. Climate change and world food security. In Proceedings of the NATO advanced research workshop, 11-15 July 1993, Oxford UK. Springer, Heidelberg, Germany.
Dunn, W. N. 2004. Public policy analysis: an introduction. Third edition. Pearson Education LTD, Upper Saddle River, New Jersey, USA.

Ehui, S., and J. Pender. 2005. Resource degradation, low agricultural productivity, and poverty in subSaharan Africa: pathways out of the spiral. Pages 225-242 in D. Colman and N. Vink, editors. Reshaping agriculture's contributions to society. Proceedings of the 25th International Conference of Agricultural Economists, August 2003, Durban, South Africa, Blackwell Publishing, Oxford, UK.

Food and Agriculture Organization (FAO). 2002. The state of food insecurity in the world. Food and Agriculture Organization of the United Nations, Rome, Italy.

Federal Democratic Republic of Ethiopia (FDRE). 1994. An economic development strategy for Ethiopia. Federal Democratic Republic of Ethiopia (FDRE), Addis Ababa, Ethiopia.

Federal Democratic Republic of Ethiopia (FDRE). 2001. Federal Democratic Republic of Ethiopia (FDRE) Food security strategy. Updated version. Addis Ababa, Ethiopia.

Feleke, S. T., R. L. Kilmer, and C. H. Gladwin. 2005. Determinants of food security in Southern Ethiopia at the household level. Agricultural Economics 33:351-363.

Frankenberger, T. R. 1992. Indicators and data collection methods for assessing household food security. International Fund for Agricultural Development (IFAD), Rome, Italy.

Gilligan, D. O., and J. Hoddinott. 2007. Is there persistence in the impact of emergency food aid? Evidence on consumption, food security, and assets in rural Ethiopia. American Journal of Agricultural Economics 89:225-242.

Govereh, J., and T. S. Jayne. 1999. Effects of cash crop production on food crop productivity in Zimbabwe: synergies or trade-offs? Department of Agricultural Economics and the Department of Economics, Michigan State University, East Lansing, Michigan, USA.

Gujarati, D. 2003. Basic econometrics. Fourth edition. McGraw-Hill Companies, New York, New York, USA. 
Hoddinott, J. 1999. Operationalizing household security and development strategies. An introduction. Technical guideline No 1, International Food Policy Research Institute, Washington, D.C., USA

Hofferth, S. 2004. Persistence and change in the food security of families with children, 1997-1999. Economic Research Service, U.S. Department of Agriculture, Washington, D.C., USA.

Holden, S., C. B. Barrett, and F. Hagos. 2006. Foodfor-work for poverty reduction and the promotion of sustainable land use: Can it work? Environment and Development Economics 11:15-38.

Holden, S., and B. Shiferaw. 2004. Land degradation, drought and food security in a lessfavoured area in the Ethiopian highlands: a bioeconomic model with market imperfections. Agricultural Economics 30:31-49.

Holden, S., B. Shiferaw, and J. Pender. 2004. Nonfarm income, household welfare, and sustainable land management in a less-favoured area in the Ethiopian highlands Food Policy 29:369-392.

Hosmer, D., and S. Lemeshew. 1989. Applied logistic regression. Wiley InterScience, New York, New York, USA.

Kumar, R. 2005. Research methodology. A step-bystep guide for beginners. SAGE, Thousand Oaks, California, USA.

Loening, J., and L. M. Imru. 2009. Ethiopia: diversifying the rural economy. An assessment of the investment climate for small and informal enterprises. Report No. 49564-ET. World Bank, Washington, D.C., USA.

Maxwell, S. 2001. The evolution of thinking about food security. In S. Devereux and S. Maxwell, editors. Food security in sub-Saharan Africa. ITDG, London, UK.

Maxwell, S., and T. Frankenberger. 1992. Household food security: concepts, indicators and measurements: a technical review. UNICEF and International Fund for Agricultural Development (IFAD), New York, New York, USA, and Rome, Italy.

Maxwell, S., and M. Smith. 1992. Household food security: a conceptual review. in S. Maxwell and T. Frankenberger, editors. Household food security: concepts, indicators and measurements: a technical review. UNICEF and International Fund for Agricultural Development (IFAD), New York, New York, USA, and Rome, Italy.

Ministry of Finance and Economic Development (MoFED). 2002. Ethiopia: sustainable development and poverty reduction program. Ministry of Finance and Economic Development, Federal Democratic Republic of Ethiopia, Addis Ababa, Ethiopia.

Najafi, B. 2003. An overview of current land utilization systems and their contribution to agricultural productivity. In L. S. Willardson, editor. Report of the APO Seminar on impact of land utilization systems on agricultural productivity, November 2000, Islamic Republic of Iran. Asian Productivity Organization, Tokyo, Japan.

Nyariki, D. M., S. L. Wiggins, and J. K. Imungi. 2002. Levels and causes of household food and nutrition insecurity in dryland Kenya. Ecology of Food and Nutrition 41:155-176.

Nyssen, J., H. Vandenreyken, J. Poesen, J. Moeyersons, J. Deckers, Mitiku Haile, C. Salles, and G. Govers. 2005. Rainfall erosivity and variability in the Northern Ethiopian Highlands. Journal of Hydrology 311:172-187.

Paarlberg, R. L. 2002. Governance and food security in an age of globalization. 2020 Vision for Food, Agriculture, and the Environment, Discussion Paper 36. International Food Policy Research Institute (IFPRI), Washington, D.C., USA.

Pender, J., and B. Gebremedhin. 2008. Determinants of agricultural and land management practices and impacts on crop production and household income in the highlands of Tigray, Ethiopia. Journal of African Economies 17:395-450.

Quisumbing, A. R. 2003. Food aid and child nutrition in rural Ethiopia. World Development 31:1309-1324.

Sen, A. 1981. Poverty and famine: an essay on entitlement and deprivation. Oxford University Press, Oxford, UK.

Tewolde Berhan, G. E. 2006. The role of forest rehabilitation for poverty alleviation in drylands. Journal of the Drylands 1:3-7. 
von Braun, J. 1991. Policy agenda for famine prevention in Africa. Food Policy Report No. 13. International Food Policy Research Institute (IFPRI), Washington, D.C., USA.

Webb, P., and J. von Braun. 1994. Famine and food security in Ethiopia: lessons for Africa. John Wiley $\&$ Sons, Chichester, New York, USA.

Wond, T., and M. Macaulay. 2010. Evaluating local implementation: an evidence-based approach. Policy and Society 29:161-169.

Yamano, T., H. Alderman, and L. Christiaensen. 2005. Child growth, shocks and food aid in rural Ethiopia. American Journal of Agricultural Economics 87:273-288. 


\begin{tabular}{|c|c|c|c|}
\hline \multirow[b]{2}{*}{$\mathrm{S} / \mathrm{N}$} & \multirow[b]{2}{*}{ District } & \multicolumn{2}{|c|}{ Growth rate } \\
\hline & & $\begin{array}{c}\text { Self Sufficiency Ratio } \\
\text { (SSR) }\end{array}$ & $\begin{array}{c}\text { Food Availability } \\
\text { Ratio (FAR) }\end{array}$ \\
\hline 1 & Adwa & 54.6 & 25 \\
\hline 2 & Ahferom & 77.8 & 3.2 \\
\hline 3 & Alaje & 112.9 & 39 \\
\hline 4 & Alamata & 13.4 & 1.9 \\
\hline 5 & Asegede Tsimbla & 14.2 & 15.2 \\
\hline 6 & Atsbi Womberta & 46.7 & 6.1 \\
\hline 7 & Degua Temben & 13.5 & 2.5 \\
\hline 8 & Endamehoni & 29.8 & 8.7 \\
\hline 9 & Enderta & 46.3 & 21.1 \\
\hline 10 & Erob & 29.2 & 16.3 \\
\hline 11 & Ganta Afeshum & 45.6 & 3.5 \\
\hline 12 & Gulomekeda & 68.3 & 17.9 \\
\hline 13 & Hawezen & 54 & 18.9 \\
\hline 14 & Hintalo Wajerat & 41.3 & 24.2 \\
\hline 15 & Kafta Humera * & - & - \\
\hline 16 & Kilte Awelaelo & 66.7 & 11.2 \\
\hline 17 & Kola Temben & 16.6 & 3.2 \\
\hline 18 & Laelay Adiyabo & 27.4 & 28 \\
\hline 19 & Laelay Maichew & 0 & -4.8 \\
\hline 20 & Medebay Zana & 11.6 & 8.8 \\
\hline 21 & Merebleke & 20.2 & 33.2 \\
\hline 22 & Naeder Adet & $\begin{array}{l}-6.1 \\
\end{array}$ & -1.8 \\
\hline 23 & Ofla & 12.5 & 8.7 \\
\hline 24 & Raya Azebo & 143.2 & 160 \\
\hline 25 & Saesie Tsaeda Emba & 61.6 & 17.5 \\
\hline 26 & Saharti Samere & 9.6 & 1.3 \\
\hline 27 & Tahetay Adiyabo & 169.1 & 117.8 \\
\hline 28 & Tahetay Koraro & 11.5 & 16.1 \\
\hline 29 & Tahetay Maichew & 19.7 & 7 \\
\hline 30 & Tanqua Abergele & 70.6 & 20.8 \\
\hline 31 & Tsegede & 36.2 & 36.2 \\
\hline 32 & Tselemti & 31.1 & 12.8 \\
\hline 33 & Welkait & 24.8 & 13.4 \\
\hline 34 & Werieleke & 18.5 & 0.1 \\
\hline
\end{tabular}

* This district was not included in the analysis because the majority of farms in it are owned by investors. 